\title{
Edukasi Penyakit Diabetes Melitus dan Cara Pemeriksaan Glukosa Darah Secara Mandiri
}

\author{
Tri Agusti Sholikah ${ }^{1}$, Ratih Puspita Febrinasari², Dyonisa Nasirochmi Pakha ${ }^{3}$ \\ 1. Bagian Histologi, Fakultas Kedokteran Universitas Sebelas Maret, Surakarta \\ 2. Bagian Farmakologi, Fakultas Kedokteran Universitas Sebelas Maret, Surakarta \\ 3. Fakultas Kedokteran Universitas Sebelas Maret, Surakarta
}

\begin{abstract}
ABSTRAK
Pendahuluan: Diabetes Melitus (DM) merupakan salah satu penyakit metabolik kronis yang masih menjadi perhatian di dunia. Penyakit ini ditandai dengan tingginya kadar glukosa pada sirkulasi darah atau disebut dengan hiperglikemia. Deteksi dini penyakit DM dan pemantauan kadar glukosa darah pada penderita DM sangatlah penting untuk dilakukan. Hal tersebut dikarenakan kadar glukosa darah yang sangat tinggi atau tidak terkontrol akan menyebabkan terjadinya komplikasi serius di berbagai organ tubuh. Hal ini dapat meningkatkan morbiditas dan mortalitas pasien. Saat ini telah tersedia alat pemeriksaan glukosa darah yang mudah digunakan masyarakat yaitu glukometer. Namun, nampaknya masih banyak masyarakat yang belum terampil menggunakannya. Selain itu banyak masyarakat yang belum memahami penyakit DM secara holistik sehingga perlu dilakukan kegiatan pengabdian masyarakat tentang penyakit DM.

Metode: Pengabdian masyarakat ini berupa edukasi tentang penyakit DM secara holistik melalui penyebaran video di grup-grup Whatsapp, Instagram, Facebook dan Youtube. Video edukasi tersebut terdiri dari 3 buah video, yaitu video tentang penyakit DM secara holistik, video cara penggunaan glukometer untuk memeriksa glukosa darah, dan video tentang DM di era COVID-19. Setelah disebarkan, masyarakat diminta memberikan respon melalui kuesioner.

Hasil dan pembahasan: Sebanyak 33 dari 36 (92\%) responden setuju dan sangat setuju bahwa video yang diunggah membuat mereka menjadi lebih paham mengenai penyakit DM dan cara menggunakan glukometer.

Kesimpulan: Kegiatan pengabdian kepada masyarakat dapat meningkatkan pengetahuan dan pemahaman masyarakat mengenai penyakit DM dan cara memeriksa glukosa darah secara mandiri dengan glukometer.
\end{abstract}

Kata Kunci: Diabetes Melitus; Glukosa Darah; Glukometer

\begin{abstract}
Introduction: Diabetes Melitus (DM) is one of the chronic metabolic diseases which still becomes a global issue. This disease is characterized by a high level of glucose in the blood (hyperglycemia). Early detection and monitoring of blood glucose levels are essential. These happen because many serious complications could occur if the blood glucose level is too high or uncontrolled. Also, these complications will increase the morbidity and mortality of patients. Recently, there is a glucometer (a blood glucose test tool) that is helpful for the public to check their blood glucose level. However, the majority of people do not know how to operate this tool. Moreover, most of them have not understood DM completely. Therefore, it is very important to carry out community service about DM.

Methods: The method of this community service was educating people about DM by using three videos. These three videos were about DM as holistic, how to use the glucometer, and DM in era pandemic COVID19. Then, these videos were socialized through WhatsApp group, Instagram, Facebook, and YouTube. Later, we used a questionnaire to understand the response of the community.

Results and discussions: A total of 33 out of 36 (92\%) respondents agreed and strongly agreed that the videos helped them to understand more about DM and how to use the glucometer.

Conclusion: This community service increases the knowledge and understanding of the community about Diabetes Melitus and how to check blood glucose independently with a glucometer.
\end{abstract}

Keywords: Diabetes Melitus; Blood Glucose; Glucometer

Correspondence: Tri Agusti Sholikah, dr.M.Sc, Universitas Sebelas Maret, triagusti_sholikah@staff.uns.ac.id 


\section{PENDAHULUAN}

Diabetes Melitus (DM) merupakan salah satu penyakit metabolik kronis yang ditandai dengan meningkatnya kadar glukosa pada sirkulasi darah atau disebut dengan hiperglikemia ${ }^{1}$. Penyakit ini menjadi masalah kesehatan yang serius karena merupakan penyebab morbiditas dan mortalitas masyarakat di berbagai belahan dunia terutama di negara berkembang termasuk Indonesia. Oleh karena itu, DM masih menjadi perhatian dunia saat ini² ${ }^{2}$

Prevalensi DM cukup tinggi dan jumlahnya terus meningkat dengan cepat. Pada tahun 2015, jumlah penderita DM di dunia mencapai 415 jiwa dan diperkirakan pada tahun 2040 mencapai 642 jiwa $^{3}$. Sedangkan menurut data Global Status Report on NCD WHO tahun 2014, terdapat 422 juta jiwa di dunia menderita DM dan setiap tahunnya terdapat 1,5 juta jiwa yang meninggal dunia ${ }^{4}$. Indonesia merupakan negara yang menduduki peringkat ke-7 jumlah penderita DM terbanyak di dunia ${ }^{5}$. Menurut Departemen Kesehatan RI pada tahun 2013, terdapat jumlah pasien DM di Indonesia sebanyak 12,1 juta jiwa dan diperkirakan jumlahnya akan terus meningkat ${ }^{6}$.

Hiperglikemia yang terjadi pada penyakit DM disebabkan karena rusaknya sel $\beta$ pankreas sehingga insulin tidak dapat diproduksi (defisiensi insulin) dan atau karena gangguan sensitivitas insulin di jaringan perifer (resistensi insulin) sehingga glukosa tidak dapat digunakan oleh sel ${ }^{1,7}$. Hiperglikemia yang tidak terkontrol dapat mengakibatkan komplikasi yang serius pada berbagai organ tubuh. Komplikasi tersebut diantaranya komplikasi pada jantung dan pembuluh darah seperti areteriosklerosis, penyakit jantung koroner dan kardiomyopati; pada mata (retinopati), pada saraf (neuropati) dan pada ginjal (nefropati). Hal tersebutlah yang tentunya meningkatkan morbiditas dan mortalitas pasien DM. Oleh karena itu, hiperglikemia pada pasien DM perlu diterapi ${ }^{8,9}$.

Berdasarkan etiologinya terdapat 3 tipe DM yaitu DM tipe 1, DM tipe 2 dan DM tipe gestational. DM tipe 2 merupakan jenis DM yang paling sering ditemukan dengan angka kejadian 90-95\% dari keseluruhan kasus $\mathrm{DM}^{10}$. Tipe ini ditandai dengan resistensi insulin dan defisiensi insulin yang relatif. Hal yang menjadi faktor resiko DM ini adalah obesitas dan gaya hidup yang tidak baik ${ }^{1}$.

Seseorang yang menderita DM mempunyai gejala klasik yaitu poliuri (banyak kencing), polidipsi (banyak minum), polifagi (banyak makan) dan menurunnya berat badan tanpa sebab yang jelas ${ }^{11}$. Diagnosis DM salah satunya dapat ditegakkan apabila dijumpai gejala klasik tersebut dan disertai kadar glukosa darah sewaktu $\geq 200 \mathrm{mg} / \mathrm{dL}^{1}$.

Deteksi dini penyakit DM dan pemantauan kadar glukosa darah pada penderita DM sangatlah penting untuk dilakukan. Hal tersebut dikarenakan agar tidak terjadi komplikasi serius di berbagai organ tubuh. Saat ini telah tersedia alat pemeriksaan glukosa darah yang mudah digunakan masyarakat yaitu glukometer, namun nampaknya masih banyak masyarakat terutama masyarakat di wilayah kerja Puskesmas Purwodiningratan yang belum terampil menggunakannya. Selain itu masih banyak masyarakat yang belum memahami penyakit DM secara holistik sehingga perlu dilakukan kegiatan pengabdian masyarakat yang berupa edukasi tentang penyakit DM dan cara menggunakan glukometer. Kegiatan pengabdian ini khususnya ditujukan untuk masyarakat di wilayah kerja Puskesmas Purwodiningratan dan juga masyarakat luas pada umumnya. Diharapkan dengan adanya kegiatan ini, masyarakat menjadi semakin paham tentang penyakit DM serta dapat melakukan pemeriksaan glukosa darah secara mandiri. 


\section{METODE}

Mengingat terjadi pandemi global COVID-19, maka tidak memungkinkan untuk pemberian edukasi secara langsung dengan mengumpulkan masyarakat. Oleh karena itu, pengabdian kepada masyarakat ini dilakukan dengan pembuatan video edukasi. Pembuatan video edukasi berjumlah 3 buah yang bertema tentang Penyakit Diabetes Melitus secara holistik, cara penggunaan glukometer untuk memeriksa glukosa darah, dan pasien diabetes Melitus di era COVID-19. Masing-masing video berdurasi selama 3 menit.

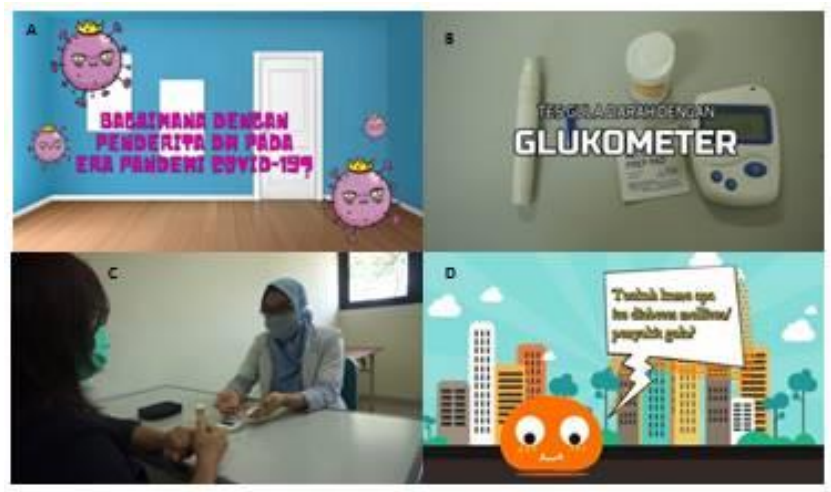

Gambar 1. Tangkapan layar video. A. DM di era COVID-19. B \& C. Cara menggunakan glukometer. D. Penyakit DM

Video yang telah dibuat kemudian disebarkan melalui grup Whatsapp yang beranggotakan warga masyarakat di wilayah kerja Posbindu binaan Puskesmas Purwodiningratan dan juga grup Whatsapp yang lain. Selain itu, video edukasi juga disebarkan melalui media sosial instagram, facebook dan youtube untuk menjangkau masyarakat luas. Di media sosial youtube, video dapat diakses melalui link https://youtu.be/arVfNHDQ5yQ untuk video dengan tema edukasi penyakit diabetes melitus, https://youtu.be/EuMhW2upLCA untuk video diabetes melitus di era covid 19 dan https://youtu.be/12pCQHQIvf0 untuk video mengenai penggunaan glukometer. Tangkapan layar ketiga video yang telah dibuat dan disebarkan dapat dilihat pada gambar 1.

Saat penyebaran video, tim pengabdi juga memberikan link kuesioner yang bisa diisi masyarakat sebagai tanggapan terhadap video tersebut. Isi kuesioner berupa pertanyaanpertanyaan yaitu yang pertama apakah responden dapat lebih memahami penyakit diabetes melitus setelah melihat video "Edukasi Diabetes Melitus", kedua apakah responden lebih memahami tentang bagaimana pasien diabetes melitus seharusnya bersikap pada era COVID-19 setelah melihat video "Diabetes Melitus di era COVID-19", ketiga apakah responden dapat memahami pengguaan alat glukometer setelah melihat video "Edukasi Penggunaan Glukometer", dan yang keempat bagaimana tanggapan responden terhadap ketiga video tersebut. Untuk pertanyaan no 1 sampai 3 diberi skor 1 (sangat tidak setuju) sampai 5 (sangat setuju), sedangkan pertanyaan yang keempat berupa jawaban singkat.

Kegiatan pengabdian kepada masyarakat ini mempunyai 3 target capaian yaitu yang pertama masyarakat dapat menjadi semakin paham mengenai penyakit diabetes Melitus, yang kedua masyarakat dapat menggunakan glukometer dengan benar sehingga dapat melakukan pemeriksaan glukosa darah secara mandiri dan yang terakhir masyarakat terutama penderita diabetes melitus semakin paham tentang bagaimana sikap yang harus dilakukan di era COVID19. Ketiga target tersebut diharapkan dapat tercapai dengan selesainya kegiatan ini. Ethical 
clearance pengabdian masyarakat ini bernomor 124/UN.27/KEPK/2020 dikeluarkan oleh Komite Etik Penelitian Kesehatan Fakultas Kedokteran Universitas Sebelas Maret.

\section{HASIL DAN PEMBAHASAN}

Sejumlah 36 responden memberi tanggapan melalui link yang diberikan sehari setelah video diunggah di media sosial dan disebar ke grup Whatsapp. Semua responden memberi tanggapan bahwa video yang diunggah bagus, edukatif, dan membantu masyarakat memahami penyakit DM serta dapat menggunakan glukometer. Namun, ada 1 responden yang menyayangkan durasi video yang terlalu lama.

Pada gambar 2, tampak terlihat hasil responden terkait pertanyaan kuesioner mengenai apakah responden menjadi lebih paham tentang penyakit DM setelah melihat video. Hasil kuesioner menunjukkan 33 dari 36 responden (91.67\%) setuju menjadi lebih paham akan DM. Diabetes melitus merupakan penyakit kronis yang masih menjadi perhatian di dunia, termasuk Indonesia ${ }^{2}$. Ketika seseorang mengalami gejala Diabetes Melitus, informasi mengenai Diabetes Melitus di Indonesia dapat diperoleh melalui pembelajaran aktif maupun pasif. Pembelajaran aktif terjadi ketika seseorang mencari informasi secara aktif atau bertanya kepada ahlinya ${ }^{12}$. Salah satu sumber informasi yang digunakan dalam pengabdian ini adalah video animasi yang mencakup informasi diabetes melitus secara keseluruhan. Oleh karena itu, video ini membantu mereka yang sedang ingin memahami lebih lanjut mengenai Diabetes Melitus ataupun yang ingin mengetahui apa yang terjadi pada tubuhnya.

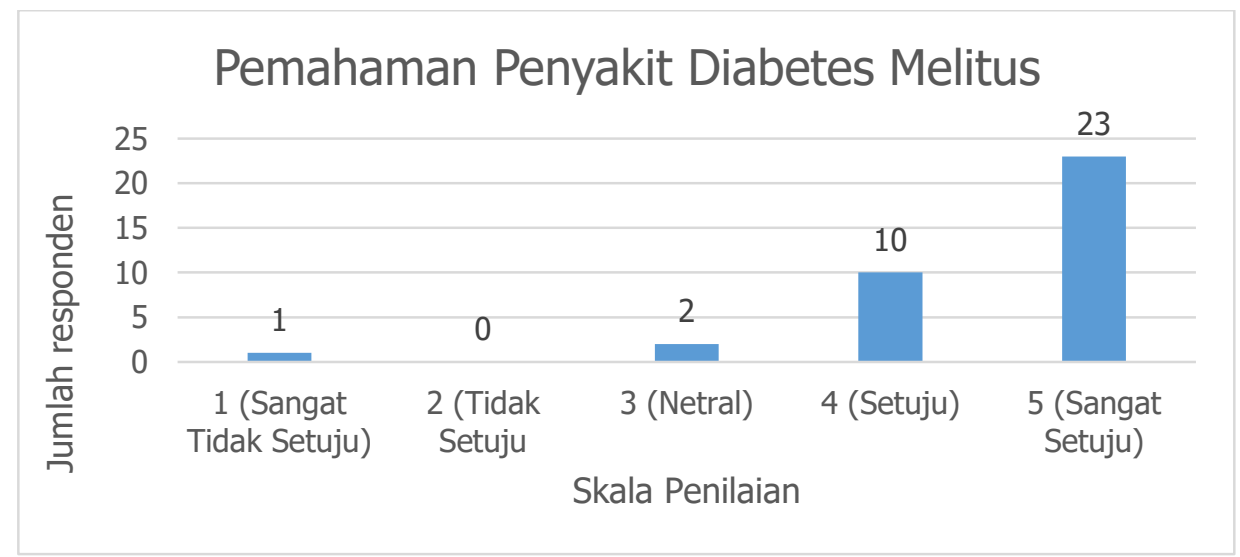

Gambar 2. Distribusi responden tentang pemahaman penyakit DM setelah melihat video.

Adanya pandemi COVID-19 menyebabkan penurunan kunjungan ke fasilitas kesehatan dikarenakan ketakutan terkena COVID-19 ${ }^{13}$. Akibatnya, masyarakat akan kesulitan dalam memonitor glukosa darah mereka. Oleh karena itu, video "Edukasi Penggunaan Glukometer" ditujukan untuk membantu meningkatkan pemahaman masyarakat dalam menggunakan alat glucometer secara mandiri. Berdasarkan gambar 3, tampak bahwa 91.67\% setuju bahwa video meningkatkan pemahaman mereka dalam menggunakan glukometer. Namun, 13.89\% masih kurang paham akan penggunaan alat tersebut. Hal ini dimungkinkan karena masyarakat tidak dapat mempraktikkan penggunaan glukometer secara langsung. 


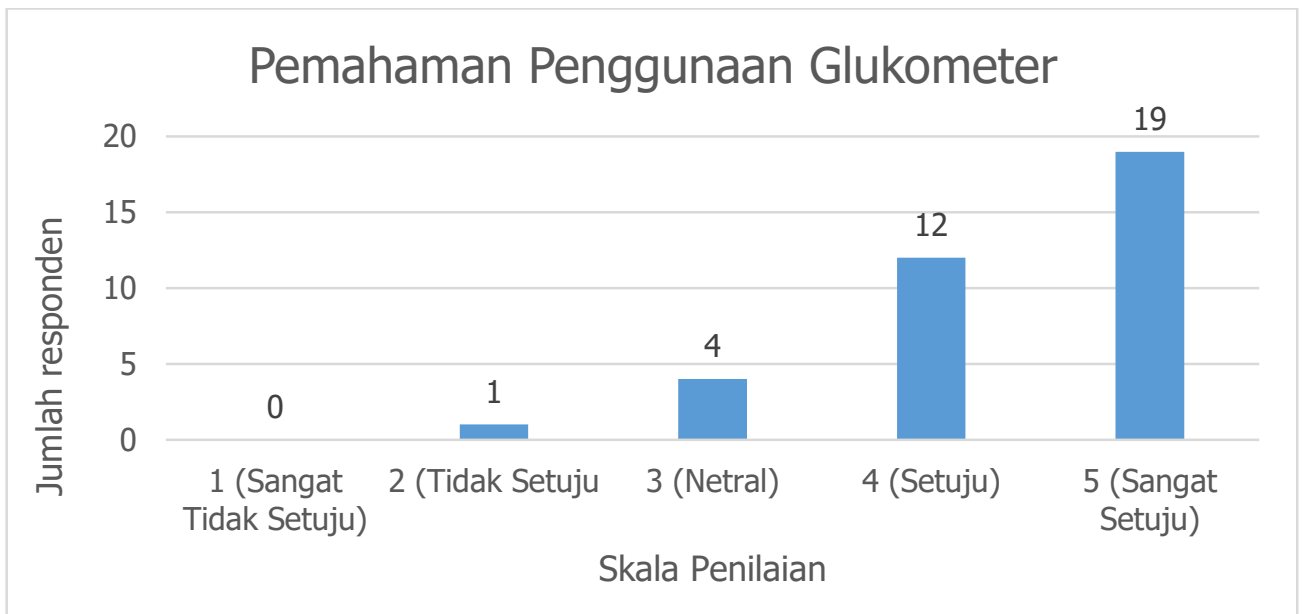

Gambar 3. Distribusi responden tentang pemahaman penggunaan glukometer setelah melihat video.

Berdasarkan studi yang dilakukan oleh Chinese Centre for Disease Control ditemukan bahwa kasus kematian pada pasien COVID-19 yang menderita DM lebih tinggi (7.3\%) daripada mereka yang tidak memiliki DM $(2.3 \%)^{14}$. Sehingga diperlukan sebuah video untuk menginformasikan sikap apa yang dapat dilakukan oleh penderita Diabetes Melitus di era pandemi COVID-19. Dari gambar 4, tampak $94.44 \%$ setuju bahwa mereka memahami apa yang harus mereka lakukan untuk berperilaku di era pandemi ini.

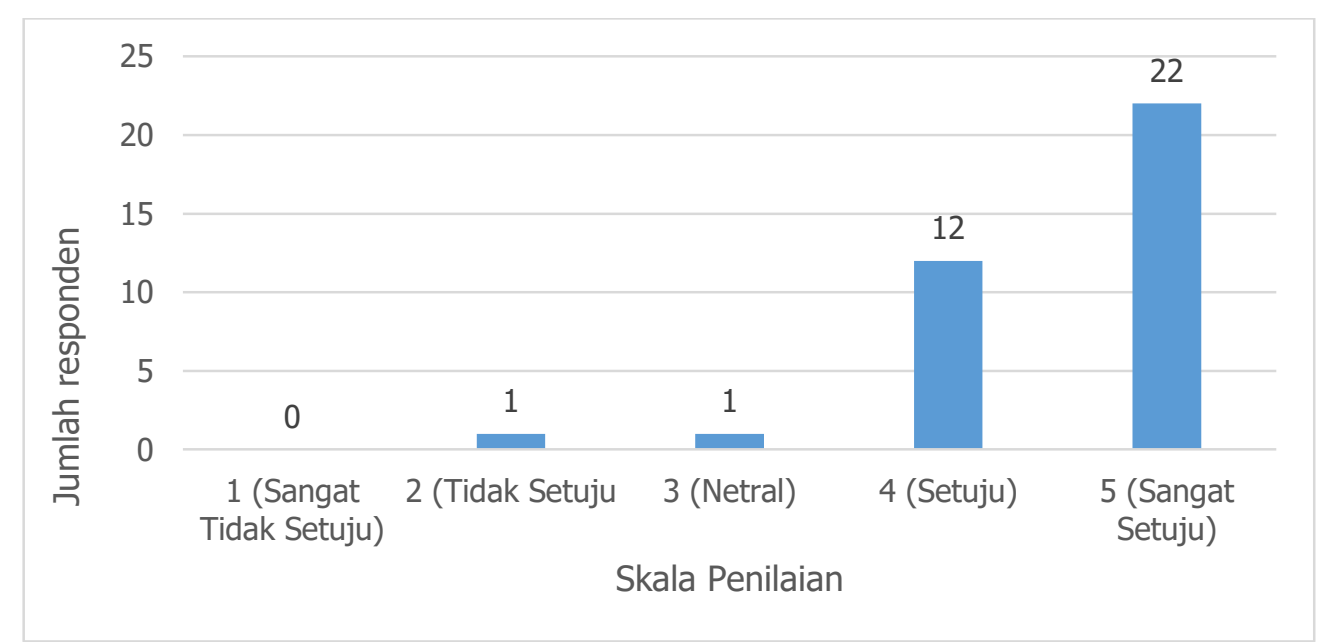

Gambar 4. Distribusi responden tentang pemahaman bagaimana pasien DM harus bersikap di era COVID-19 setelah melihat video.

Berdasarkan hasil-hasil yang telah disebutkan diatas dapat diketahui bahwa lebih dari $90 \%$ responden menyatakan setuju bahwa setelah melihat video yang diunggah mereka menjadi lebih paham tentang penyakit diabetes melitus dan menjadi paham cara menggunakan glukometer. Hal ini dapat dikaitkan dengan penggunaan media video dalam edukasi. Penggunaan video dapat meningkatkan proses dalam mencerna informasi dibandingkan hanya ilustrasi ${ }^{15}$. Video yang dibuat juga diikutkan dengan suara sehingga dapat memudahkan terutama bagi mereka yang memiliki literasi kesehatan yang rendah ${ }^{15}$. Selain itu, adanya audio mengurangi terjadinya cognitive overload yang dapat menghambat pemrosesan informasi ${ }^{15}$. Adanya sebagian kecil angka yang belum memahami video dapat disebabkan antara lain adanya distraksi dari animasi 
dan cognitive overload karena memproses animasi. Akibatnya, responden ini akan cenderung memperhatikan animasi daripada konten ${ }^{15}$.

Dengan demikian target yang diharapkan dari kegiatan pengabdian kepada masyarakat ini bisa tercapai. Dengan semakin pahamnya masyarakat tentang penyakit diabetes melitus, diharapkan angka morbiditas dan mortalitas penyakit DM semakin menurun ${ }^{16}$. Selain itu, dengan pahamnya masyarakat bagaiamana cara menggunakan glukometer secara benar maka diharapkan masyarakat mampu melakukan pemeriksaan glukosa darah secara mandiri untuk deteksi dini penyakit DM dan juga untuk memantau kadar glukosa darah bagi penderita DM.

\section{KESIMPULAN}

Kegiatan pengabdian kepada masyarakat tentang penyakit DM yang dilakukan secara daring melalui video ini dapat menambah pengetahuan dan pemahaman masyarakat mengenai penyakit DM dan cara memeriksa glukosa darah secara mandiri dengan glukometer.

\section{UCAPAN TERIMA KASIH}

Pengabdi mengucapkan terima kasih yang sebesar-besarnya kepada Lembaga Penelitian dan Pengabdian kepada Masyarakat (LPPM) Universitas Sebelas Maret atas support dananya, staf dan masyarakat di wilayah kerja Puskesmas Purwodiningratan Surakarta, responden yang telah berpartisipasi serta seluruh pihak yang telah membantu terlaksananya kegiatan pengabdian ini.

\section{DAFTAR PUSTAKA}

1. American Diabetes Association. Diagnosis and classification of diabetes Melitus. Diabetes Care 2014; 37(Supplement 1): S81-S90.

2. Suyono, S. Diabetes Melitus di Indonesia. Dalam: Sudoyo AW, Setiyohadi B, Alwi I, Simadibrata, MI (eds). Buku Ajar Ilmu Penyakit dalam. Jakarta: Pusat Penerbitan Departemen Peyakit Dalam Fakultas Kedokteran Universitas Indonesia; 2009.

3. International Diabetes Federation. IDF Diabetes Atlas Seventh Edition. United Kingdom: IDF; 2015.

4. World Health Organization (WHO). WHO | About Diabetes [Online]. 2014. [Sitasi: 4 May 2018]. Diunggah dari: https://web.archive.org/web/20140331094533/http://www.who.int/diabetes/action_onlin e/basics/en/

5. Soewondo, P., Ferrario, A., \& Tahapary, D.L. Challenges in diabetes management in Indonesia: a literature review. Globalization and Health 2013; 9 (1): 63.

6. Departement Kesehatan Republik Indonesia (Depkes RI). Infodatin-Diabetes. 2013. [Sitasi: 27 April 2018]. Diunggah dari: http://www.depkes.go.id/resources/download/pusdatin/infodatin/infodatin-diabetes.pdf

7. Madihah, Fitiani, A., \& Yetty, Y. G. Kadar glukosa darah dan gambaran histologis pankreas pencit (Mus musculus L.) yang diinduksi aloksan setelah perlakuan ekstrak rimpang temu mangga (Curcuma mangga Val.). Jurnal Biologi 2016; 20 (2): 64-68.

8. Fowler, M.J. Microvascular and Macrovascular Complications of Diabetes. Clinical Diabetes 2008; 26:77-82. 
9. Chawla A, Chawla R, Jaggi S. Microvascular and macrovascular complications in diabetes Melitus : distinct or continuum. Indian J Endocrinol Metab 2016; 20(3):546-551

10. Centers for Disease Control and Prevention (CDC). Type 2 Diabetes | Basics | Diabetes | CDC [Online]. 2018. [sitasi 28 Jan 2020]. Diunggah dari: https://www.cdc.gov/diabetes/basics/type2.html].

11. Sudoyo, A.W., Setiyohadi, B., Alwi, I., Simadibrata, M.K., \& Setiati, S. Buku ajar Ilmu Penyakit Dalam: Diabetes Melitus di Indonesia. Jakarta: Interna Publishing; 2010.

12. Ligita T, Wicking K, Francis K, Harvey N, Nurjannah I. How people living with diabetes in Indonesia learn about their disease: A grounded theory study. PLoS One. 2019;14(2):e0212019.

13. Chou, Y. C. et al. (2020) 'Impact of the COVID-19 Pandemic on the Utilization of Hospice Care Services: A Cohort Study in Taiwan', Journal of Pain and Symptom Management. Elsevier Inc, 60(3), pp. e1-e6. doi: 10.1016/j.jpainsymman.2020.07.005.

14. American Diabetes Association (2019) 'Standards of Medical Care in Diabetes - 2019. Diabetes Care', The Journal of Clinical and Applied Research and Education, 42(Suppl 1), pp. S13-28.

15. Meppelink CS, van Weert JC, Haven CJ, Smit EG. The effectiveness of health animations in audiences with different health literacy levels: an experimental study. J Med Internet Res. 2015;17(1):e11. Published 2015 Jan 13. doi:10.2196/jmir.3979

16. Nogueira, M. et al. (2020) 'Pharmaceutical care-based interventions in type 2 diabetes Melitus : a systematic review and meta-analysis of randomized clinical trials', Einstein (Sao Paulo, Brazil), 18, p. eRW4686. doi: 10.31744/einstein_journal/2020RW4686. 